\title{
椎骨動脈圧迫による顔面病攣一病因論と手術法一
}

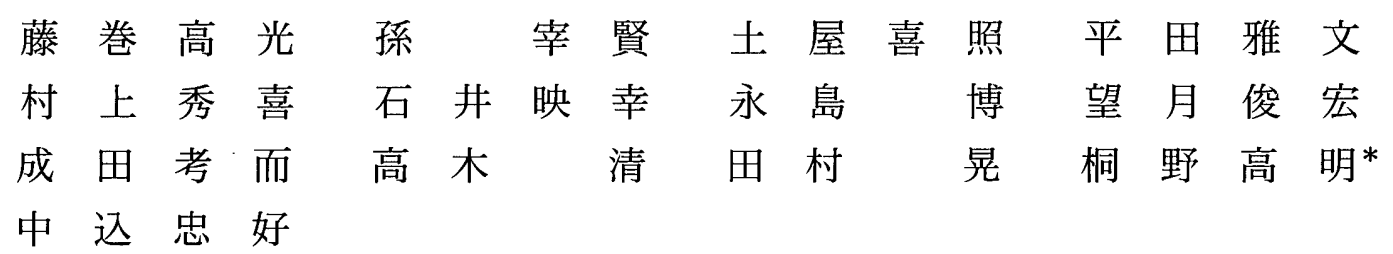

\section{Hemifacial Spasm caused by Vertebral Artery Compression : Etiological Consideration based on Demographic Data and Review of the Surgical Procedure}

by

Takamitsu Fujimaki, M.D., Ph.D., Jae-Hyun Son, M.D., Yoshiaki Tsuchiya, M.D., Ph.D., Masafumi Hirata, M.D., Hideki Murakami, M.D., Teruyuki Ishii, M.D., Ph.D., Hiroshi Nagashima, M.D., Ph.D., Toshihiro Mochizuki, M.D., Ph.D., Kouji Narita, M.D., Ph.D., Kiyoshi Takagi, M.D., Ph.D., Akira Tamura, M.D., Ph.D., Takaaki Kirino, M.D., Ph.D. * and Tadayoshi Nakagomi, M.D., Ph.D.

\section{from}

Department of Neurosurgery, Teikyo University School of Medicine, and

* Department of Neurosurgery, Faculty of Medicine, University of Tokyo

Hemifacial spasm (HFS) caused by vertebral artery (VA) compression is a condition for which the surgical approach is often complicated. Among the 199 patients who received microvascular decompression by the authors, 45 patients $(22.6 \%)$ had compression by VA or VA complexes (VA compression). In this review, patients with VA compression were analyzed. The VA compression amounted to $9.2 \%$ of the whole right side patients with HFS and $32.4 \%$ of the left side respectively. HFS was caused by VA compression in $30.5 \%$ of men whereas this figure was $17.1 \%$ in women. For the patients whose onset of the disease was at an age younger than 45 , VA compression was observed in $20.6 \%$ and for patients older than 46 , VA compression was observed in $24.5 \%$ (not significant). Also, $22.7 \%$ of patients who had hypertension had VA compression, wherea $21.9 \%$ of patients without hypertension had VA compression. Thus, not all cases with VA compression were associated with atherosclerosis. As for surgery, the vertebral artery was transposed away from facial nerve using a prosthesis of Teflon ${ }^{\circledR}$ tape and Teflon ${ }^{\circledR}$ ball under auditory brainstem response monitoring. The prosthesis should not touch the facial nerve since this will lead to failure or recurrence. The vertebral artery can also be mobilized by attaching it to the dura of the petrous bone with glue. Full care should be taken not to injure or pull out perforating arteries from the VA or basilar artery when mobilizing these arteries.

(Received July 29, 2004; accepted September 19, 2004)

Key words : hemifacial spasm, vertebral artery, vascular transposition

Jpn J Neurosurg（Tokyo） 14: 78-83, 2005

帝京大学医学部脳神経外科 $/ \bar{\top} 173-8605$ 板橋区加賀 2-11-1〔連絡先：藤巻高光〕

Address reprint requests to: Takamitsu Fujimaki, M.D., Department of Neurosurgery, Teikyo University School of Medicine, 2-111 Kaga, Itabashi-ku, Tokyo 173-8605, Japan

*東京大学医学部脳神経外科 


\section{はじめに}

片側顔面疰攣（以下, 顔面痤攣）が，顔面神経の血管 圧迫によって生じることが Gardner ら ${ }^{6)} に よ り$ 指摘さ れ,これに引き続き Jannetta $ら^{7 / 8)}$ が血管隇圧術の一連の 発表を行って以来, 約 30 年が経過している. 本手術が わが国で一般的になって 20 年が経過し, 現在では多く の施設で行われているが, 症例によっては手術が困難な 例も少なくない，機能的疾患である以上，合併症を生じ ることなくかつ確実な治猟を目指さなくてはならない. しかし, 顔面疰彎の血管による圧迫の状態は, 症例ごと に異なるといっても過言ではなく, 手術の難易度にも差 がある。一般的に手術が困難な場合と考えられるのは， 神経を圧迫血管が貫く例（第 7-8 脳神経間，あるいは神 経そのものを貫通), 圧迫血管から短い分枝が神経や脳幹 に出ている症例, そして椎骨動脈が神経圧迫に関与して いる症例である。ちなみにわが国からの顔面㾏變減圧術 の最初の報告も，奇しくも椎骨動脈圧迫例である ${ }^{11)}$.

本稿では, 自験 199 例の顔面痓卛の手術治療例の解析 より, 椎骨動脈圧迫例の病因論を示し, 手術手技の害際 を提示する.

\section{椎骨動眽圧迫の疫学}

椎骨動脈は大孔より頭蓋内に入ると小脳橋角部で屈曲 し正中に向かい, 左右が合流して脳底動脈になる。この 屈曲部が顔面神経の root exit zone（REZ）の近傍に当た る. 椎骨動脈は左右の優位性に差がある場合が多いが, 脳底動脈が非優位の椎骨動脈方向に凸に屈曲することが 多い12)。この場合, 多くの場合, 優位側の椎骨動脈は小 脳橋角部でより急峻に屈曲することになる，椎骨動脈圧 迫関与の顔面㾤攣の場合は, この屈曲する椎骨動脈また は椎骨動脈とその分枝が顔面神経を圧迫していることと なる。椎骨動脈圧迫例の頻度は, 永廣9) ${ }^{10}$ は $29.2 \sim 32 \%$ とし, Barlcer, Jannetta ら²) $23.9 \%$ と報告している. 今回のわれわれの検討では, 椎骨動脈が圧迫に関与して いた例は 45 例であった $(22.6 \%)$ 。また右側例では椎骨 動脈が関与していたのは $9.2 \%$ あっったが, 左では $32.4 \%$ であり左側例で多かった，椎骨動脈は前述のよう に優位側で屈曲が急になる傾向があるが, 剖検 81 例を 検討した Adachi ${ }^{1}$ によ扎ば右優位が $14.8 \%$, 左右同等が

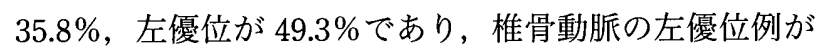
多いことが, 左側での圧迫が多いことと関連していると 考えられた。

顔面痓攣の初発年路々の相関では, 45 歳以下での発症
Table 1 Demographic data of hemifacial spasm

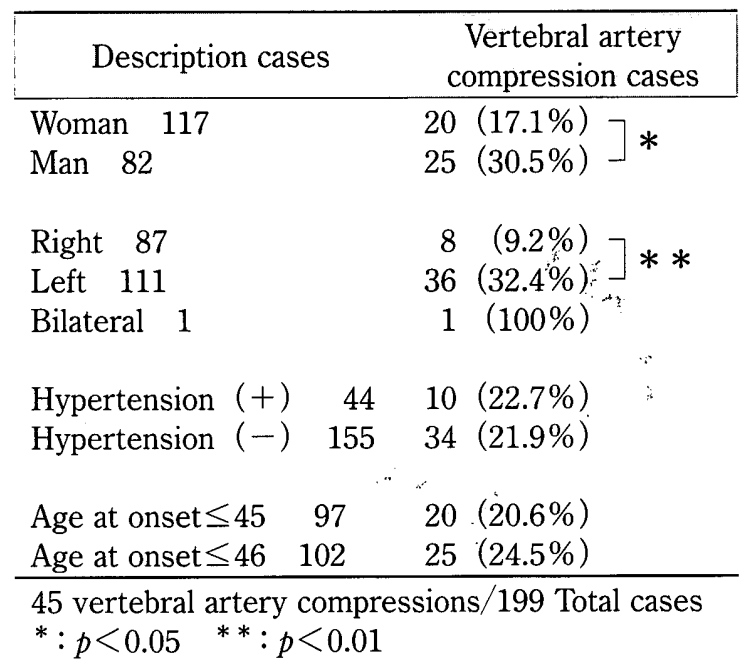

例での椎骨動脈関与例が $20.6 \%$ あっったのに対し， 46 歳 以上の例での頻度は $24.5 \%$ と若干高跉者に多い傾向を 認めるものの，有意差は認められなかった．また動脈硬 化のリスクファクターである3 高血圧症の合併の有無と の相関でも, 椎骨動脈関与例中の高血圧症合併の頻度 (22.7\%) と, 非椎骨動脈圧迫例中の高血圧症の頻度 (21.9\%) との間には, 有意差を認めなかった。一方, 性 別では男性に多かった（Table 1).

椎骨動脈の屈曲蛇行が動脈硬化と相関があるか否かに ついては，明確な記載をした文献がほとんどないが，少 なくとも若年，高血圧症を伴わない，したがって動脈硬 化を伴わない例においても，一定の確率で椎骨動脈の圧 迫関与を伴う顔面痓攣症例があることが判明した。

\section{椎骨動眽圧迫の画像診断}

術前の画像診断としてはMRI およびMRAを行う. MRI では椎骨動脈や後下小脳動脈 (posterior inferior cerebellar artery ; PICA), 前下小脳動脈 (anterior inferior cerebellar artery；AICA）の分枝, 走行状態を確認するが, 手術にあたっては MRI の画像がより重要である.椎骨動 脈圧迫例では, MRI にて顔面神経の REZ に椎骨動脈の 圧迫像が確認できる (Fig. 1). 椎骨動脈と神経との間に は PICA が挟まれることが多い. 椎骨動脈の屈曲が強く, 脳幹にくいこむように存在する症例では，圧迫部が観察 しにくいことが予想される。 また flocculus の大きい症例 では,ややりり顔面神経の REZ の観察が容易ではない. 術 前 MRI でこれらの点を検討しておく必要がある. 


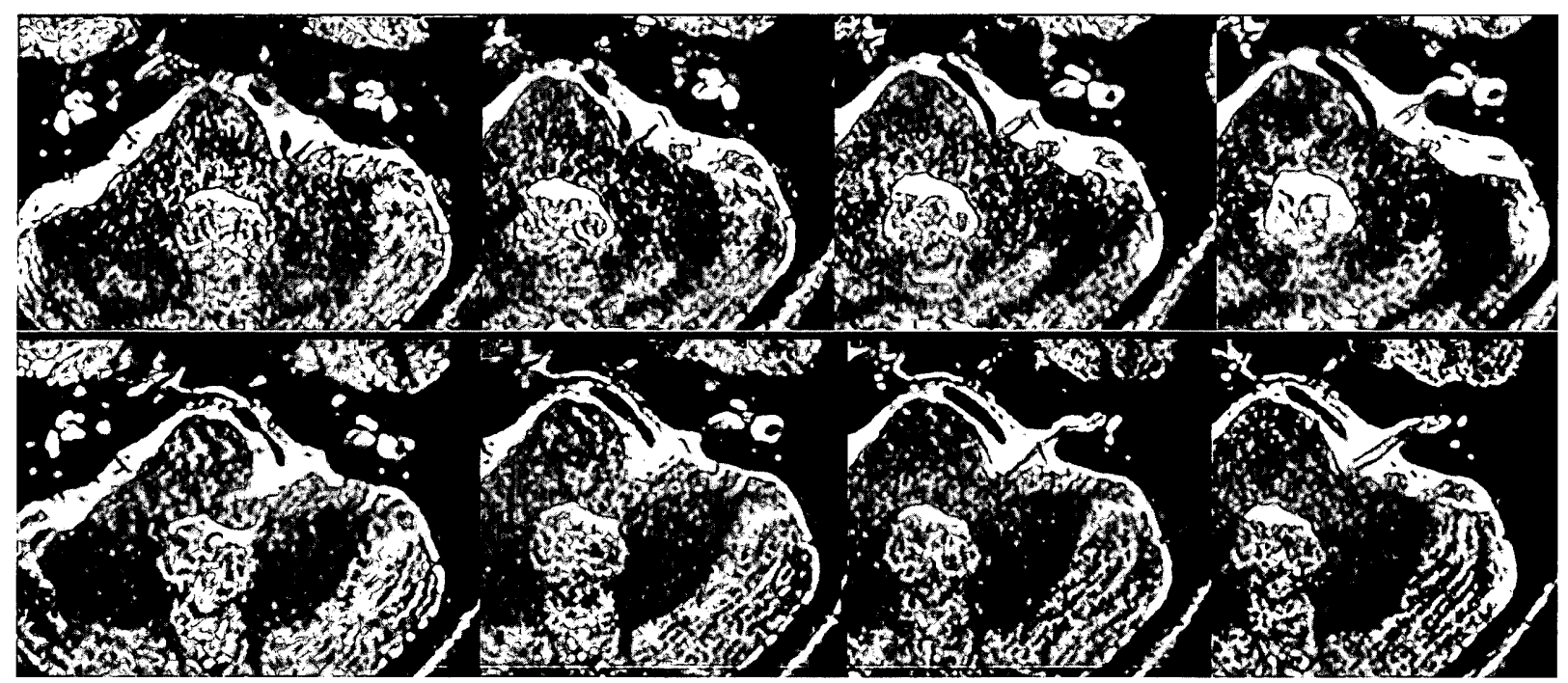

Fig. 1 Preoperative (upper) and post operative thin slice T2 MRI of 31-year-old man with left hemifacial spasm

The root exit zone is compressed by the vertebral artery (upper). The vertebral artery was transposed ventrally and the facial nerve was decompressed (lower).

\section{手術の実際}

手術は側臥位後頭下開頭で行う。あらかじめ聴性脳幹 反応 (auditory brainstem response ; ABR) 用のイヤホン と電極をセットし, 術中持続的に ABR の波形をモニ ターしつつ手術を行う。多少でも聴神経に負荷がかかつ た場合は, 手術を中断し回復を待つのを原則としている. 具体的には時村ら ${ }^{13)}$ の基準に準じて, 第 5 波の潜時が 1.5 $\mathrm{msec}$ 以上延長し, あるいは第 5 波の振幅が手術開始時の 半分以下に下がった場合，第 5 波の回復が確認されるま で手術を中断する. 乳様突起の後方に直径 $2.5 \mathrm{~cm}$ 程度の 開頭をおくべく, $4.5 \mathrm{~cm}$ ないし $5 \mathrm{~cm}$ の皮膚切開をおく. 皮膚切開は開頭予定部より後方におく.

われわれの開頭は基本的には椎骨動脈圧迫例でも小開 頭ではあるが, 他の症例よりも若干大きめの開頭として いる. 皮下よりあらかじめ筋膜を採取し, 閉頭時の硬膜 形成に備える，筋層を切開し頭蓋に至り，開頭する，前 方は S 状静脈洞ぎりぎりまで, また下方は posterior condylar emissary vein が露出されるぎりぎりまで rongeur outする. 硬膜を切開し小脸に至り, 小脳下面より approach を行う。すなわち, 小脳半球を持ち上げるよう にして lower cranial nerves を覆うクモ膜を切開して舌咽 神経の根部に至る. 舌咽神経と flocculus との間を㓦離す ると，その奥が顔面神経の REZ となる.

聴神経の保護のためには脳べらの使い方が重要で, 聴 神経の長軸方向に張力がかかる方向に, 小脳を retract す べきではない. 小脳を内耳道方向に持ち上げるように脳
べらをかけると，聴神経に対してはむしろ張力が下がる 方向となる，ある程度操作がすすむと，脳べらなしでも 手術操作が進められることも少なくない．また脳べらを 脈絡叢より深くにかけると, 腹側蝸牛神経核を圧迫する こととなり，不可逆の聴神経障害をきたす。脳べらは脈 絡叢より深部にかけないようにすべきである5).

\section{椎骨動脈圧迫例の解剖と手術手技}

顔面神経の血管圧迫に椎骨動脈が関与する場合, 解剖 学的には 3 つのパターンがある. 最も多いのは椎骨動脈 とその分枝の PICA とが圧迫する場合, 椎骨動脈と顔面 神経との間に AICA あるいは AICA と PICA が存在する 場合, また稀ではあるが, 椎骨動脈自体が直接圧迫する 場合である. Flocculus と舌咽神経との間で椎骨動脈を持 ち上げ,顔面神経の REZ を確認する．椎骨動脈から分枝 する PICA が, この部で顔面神経の直接の圧迫血管と なっていることが多い. 周囲のクモ膜を切開しつつ, 椎 骨動脈の可動性を確認する. PICA からさらに分枝が出 ていないか確認しながら, 徐々に椎骨動脈と PICA を持 ち上げていく.

本手術の目的は神経への動脈圧迫を取り除くことであ る.すなわち，血管を神経から移動して離した位置に固 定しなくてはならない. 椎骨動脈圧迫の場合, われわれ は人工血管用のテフロン®フルトより作成したテープ 状のテフロン®片4), およびこれを丸めたボール状のテフ ロン ${ }^{\circledR}$ 片を prosthesis として用いることが多い. Fig. 2 の 

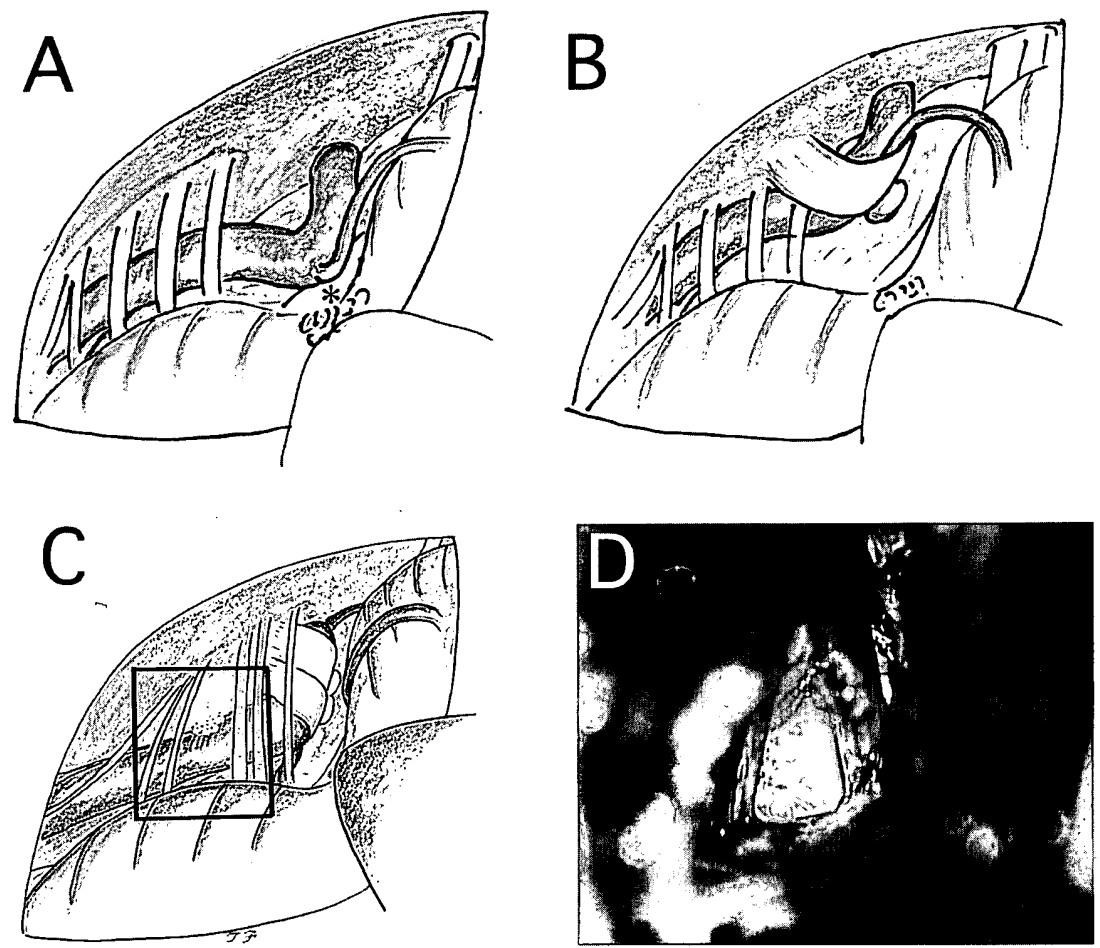

Fig. 2 Schematic drawings of vascular transposition of the vertebral artery using Teflon ${ }^{\circledR}(\mathbf{A}, \mathbf{B})$. A drawing (C) and an intraoperative photograph (D) of transposition by glue. The vertebral artery and its branch (PICA) were compressing the root exit zone $(*)$ of the facial nerve (A). The vertebral artery and PICA were transposed medially together using Teflon ${ }^{\circledR}$ tape and a Teflon ${ }^{\circledR}$ ball. The vertebral artery was fixed to the dura of the petrous bone using glue to ensure the transposition (C). The square indicates the area of intraoperative photograph shown in $\mathbf{D}$.

ように椎骨動脈と PICA をまとめて medial-caudal にず らすようにする，前述のように統計上は若年者でも圧迫 例があり，必ずしも動脈硬化と一体の病態ではないが, 年齢が高い群では動脈硬化所見もみられ，血管がより硬 いことが多い，血管の弾性が強かったり，あるいは血管 が硬いためテフロン®片で移動しても血管が戻りがちな 場合は，さらにテフロン®自体を固める目的でフィブリ ン糊を用いる ${ }^{9)}$. フィブリン糊はフィブリノゲンをゼル フォーム淿浸し,ついでトロンビン®をサージセル・ア ブソーバブル・へモスタットにに浸して局所に apply す ると,必要のないところに広がる心配がない.テフロン® に包まれて血管が移動されたら,一時的 spacer としてテ フロン®片と神経との間にはゼルフォーム祀を詰める.ゼ ルフォーム®は将来溶解, 吸収される。一方, 2 週間も するとテフロン ${ }^{\circledR}$ 周囲の硬膜などとの癒着は強固とな る.

椎骨動脈を錐体骨側に移動し，錐体骨に固定する方法 を推奨する報告もある，椎骨動脈の可動性がよく，この ような移動によって, 分枝に悪影響が及ばない場合は適
した方法である。ビオボンド®が使用できなくなった現 在, この固定にはアロンアルファ ${ }^{\circledR}$ のが用いられる. アロンアルファ ${ }^{\circledR}$ は水分に触れると瞬時に凝固するの で, 手術機器が接触しないように適切に apply する必要 がある.われわれは点滴用の留置針外筒を, $1 \mathrm{~m} l$ の注射 器につけたものにアロンアルファを吸引し, これで applyしている.

他院術後の再発, 未治癒症例の再手術で, 神経の REZ に prosthesis を詰める方法を行った症例をしばしば経験 する．REZでの prosthesis による圧迫も顔面痙攣の原因 になると考えられる. Nagahiro" ${ }^{9)}$ は自己の症例で, 椎骨動 脈圧迫例を REZ と血管との間に prosthesis を挿入した 群と，血管を transposition した群とで比較し，前者で有 意に再発率が高かったと報告している，あくまでも恒久 的に残存する prosthesis が, 顔面神経の REZ に接触しな いように血管を移動する必要がある。血管の移動にあ たっては, 主幹動脈である椎骨動脈においてはその分枝, 特に細い穿通枝に気を配る必要がある. 椎骨動脈自体は, 頭蓋内では前脊髄動脈 (anterior spinal artery), PICA 以 
外にはほとんど分枝を持たないが，脳底動脈は多くの細 かい pontine branches を持つ. 椎骨動脈の移動距離が大 きいと脳底動脈も動き，これら分枝も移動されることに なる。細い穿通枝である pontine branches は長さの余裕 がない，文献上も報告は見当たらないが，引き抜き損傷 などが起こる可能性がないとはいえない。十分に気をつ けるべき問題であると考える。

顔面神経，聴神経および血管自体以外に注意すべき構 造として，椎骨動脈の手前には下部脳神経があり，深部 やや rostral には外転神経がある. 椎骨動脈と PICA との 分岐部に，舌下神経が引っかかるように椎骨動脈を巻い て走行している場合がある。これらの神経を愛護的に扱 い，障害しないように注意する必要がある。また下部脳 神経周囲の操作では，迷走神経反射など血圧の著明な変 動をみることがあり，これにも注意が必要である。

\section{まとめ}

椎骨動脈圧迫による顔面痓攣は，動脈硬化のない若年 者でも少なからず認められ，これらの例では動脈の走行 自体がもともと顔面神経の近傍を走行していたために, 顔面痓攣を呈したものであると考えられた。一方，年齢 が高い場合は動脈硬化を伴っている、いずれの場合も他 の血管圧迫に比べ，移動，神経減圧が容易ではない場合 が多い，手術手技に習熟するとともに，適切なモニター 下に周囲の関連する解剖学的構造をよく理解しつつ, 安 全かつ確実な手術を行う必要がある。

\section{文 献}

1) Adachi B: Das Arteriensystem der Japaner, Band I. Kyoto:
Verlag der Kaiserlich-Japanischen Universitaet zu Kyoto, 1928.

2) Barker FG 2nd, Jannetta PJ, Bissonette DJ, Shields PT, Larkins MV, Jho HD: Microvascular decompression for hemifacial spasm. J Neurosurg 82: 201-210, 1995.

3) Fruchart JC, Nierman MC, Stroes ES, Kastelein JJ, Duriez $\mathrm{P}:$ New risk factors for atherosclerosis and patient risk assessment. Circulation 109: III 15-19, 2004.

4）藤巻高光, 保谷克己, 谷口 真, 鈴木一郎, 佐々木富男, 桐野高明：血管転移法による神経血管減圧術。日本脳神 経外科ビデオジャーナル 7，1999.

5) Fujimaki T, Kanemitsu A, Okinaga K, Hojo S, Takagi K, Tamura A, Nakagomi T, Kirino T: Tips for success in microvascular decompression. in Kanno T (ed) : Microvascular decompression: aiming for 100\% cure. Toyoake, Fujita Health University, 2003, pp.101-108.

6) Gardner WJ, Sava GA : Hemifacial spasm-reversible pathophysiologic state. J Neurosurg 19:240-247, 1962.

7) Jannetta PJ: The cause of hemifacial spasm: Definitive microsurgical treatment at the brainstem in 31 patients. Trans Sect Otolaryngol Am Acad Ophthalmol Otolaryngol 80:319-322, 1975.

8) Jannetta PJ, Abbasy M, Maroon JC, Ramos FM, Albin MS: Etiology and definitive microsurgical treatment of hemifacial spasm. Operative techniques and results in 47 patients. J Neurosurg 47:321-328, 1977.

9) Nagahiro S: Microvascular decompression for hemifacial spasm due to vertebral artery compression. in Kanno $\mathrm{T}$ (ed): Microvascular decompression : aiming for 100\% cure. Toyoake, Fujita Health University, 2003, pp.109-113.

10）永廣信治：顔面痤攣の病態と手術. 脳外 26:101-111, 1998.

11）鈴木一郎，佐々木亮，柳橋萬之，土田富穂，早川 勲, 小林武夫：椎骨脳底動脈系の走行異常を伴った Hemifacial Spasm の手術経験例. 脳外 6:1207-1212, 1978.

12) Takahashi $\mathrm{M}$ : Atlas of vertebral angiography, ed 1. Tokyo, Igaku Shoin, 1974.

13）時村 洋, 朝倉哲彦, 時村美香, 厚地政幸, 肝付兼能, 佐藤栄志, 福島孝徳：小脳橋角部手術における術中 $\mathrm{ABR}$ の検討 $-\mathrm{V}$ 波潜時と振幅の関係について. 脳外 18 : 1023-1027, 1990 
要 旨

椎骨動脈圧迫による顔面痙攣一病因論と手術法一

\begin{tabular}{|c|c|c|c|c|c|c|c|c|}
\hline & 高光 & 孫 & 宰賢 & 土屋 & 喜照 & 平田 & 雅文 & 村上 \\
\hline 石井 & 映幸 & 永島 & 博 & 望月 & 俊宏 & 成田 & 考而 & 高木 \\
\hline 田村 & 晃 & 桐野 & 高明 & 中込 & 忠好 & & & \\
\hline
\end{tabular}

神経血管減圧術を行った自験 199 例の顔面痙孌例のうち，椎骨動脈圧迫 45 例（22.6\%）の病態を 解析, 手術手技について解説する.

椎骨動脈圧迫は右側例の $9.2 \%$ ，左側例の $32.4 \%$ ．女性例の $17.1 \%$, 男性例の $30.5 \%$ あっった，発 症年齢 45 歳未満では $20.6 \%, 46$ 歳以上では $24.5 \%$. 高血圧合併例では $22.7 \%$ ，なしでは $21.9 \% の$ 割合であった。

以上より椎骨動脈圧迫例は左側で，男性に多いが，動脈硬化のない非高血圧，若年症例にも生じう る。減圧操作は聴性誘発脳幹電位モニター下に血管を移動させる，顔面神経を圧迫する椎骨動脈（お

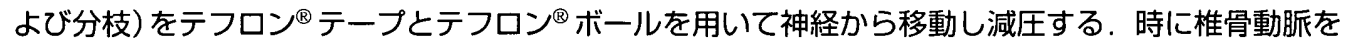
錐体骨硬膜に glue で接着. 椎骨脳底動脈の分枝を障害しないことが重要である．顔面神経，聴神経， 外転神経，下部脳神経への愛護的な丁寧な手術操作が必要である.

脳外誌 $14: 78-83,2005$

総 説

悪性グリオーマ発生の分子機序 ·佐賀大学 田㴊 和雄, 他 悪性星細胞腫の治療成績の変遷と手術療法の意義 東北大学大学院神経外科学分野 隈部 俊宏, 他 悪性グリオーマに対する放射線治療一治療最前線 ·徳島大学 影治 照喜, ·他

原 著

乳癌原発の多発脳転移に対する積極的治療 近畿大学 奥田 武司, 他 症例報告

多発外傷を伴った重症外傷性基底核部出血の 3 例 愛媛県立中央病院 松本 洋明，他 TSH 産生微小下垂体腺腫の 2 例 兵庫医科大学 池本 秀康, 他

編集の都合上内容が若干異なる場合がありますのでご了承ください. 